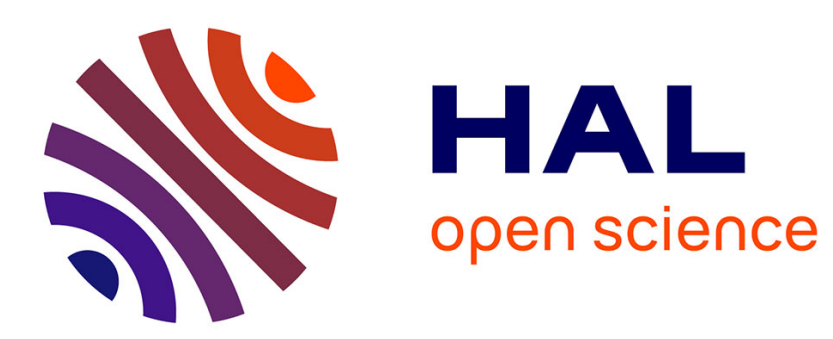

\title{
The Bank of France and the Open-Market instrument: an impossible wedding?
}

\author{
Nicolas Barbaroux
}

\section{To cite this version:}

Nicolas Barbaroux. The Bank of France and the Open-Market instrument: an impossible wedding?. 2014. halshs-01069286

\section{HAL Id: halshs-01069286 \\ https://shs.hal.science/halshs-01069286}

Preprint submitted on 29 Sep 2014

HAL is a multi-disciplinary open access archive for the deposit and dissemination of scientific research documents, whether they are published or not. The documents may come from teaching and research institutions in France or abroad, or from public or private research centers.
L'archive ouverte pluridisciplinaire HAL, est destinée au dépôt et à la diffusion de documents scientifiques de niveau recherche, publiés ou non, émanant des établissements d'enseignement et de recherche français ou étrangers, des laboratoires publics ou privés. 
The Bank of France and the Open-Market instrument: an impossible wedding?

Nicolas Barbaroux

September 2014 


\section{GATE Groupe d'Analyse et de Théorie Économique Lyon-St Étienne}

93, chemin des Mouilles 69130 Ecully - France

Tel. +33 (0)4 72866060

Fax $+33(0) 472866090$

6, rue Basse des Rives 42023 Saint-Etienne cedex 02 - France

Tel. +33(0)4 77421960

Fax. +33 (0)4 77421950

Messagerie électronique / Email : gate@gate.cnrs.fr

Téléchargement / Download : http://www.gate.cnrs.fr - Publications / Working Papers 


\title{
The Bank of France and the Open-Market instrument: an impossible wedding?*
}

\author{
BARBAROUX Nicolas $^{\dagger}$
}

\begin{abstract}
In the aftermath of the sovereign debt criss, open-market interventions prevailed within the central bank's policy answers known under the label unconventional monetary policy measures. During interwar period, France was an isolated case, among the leading countries, by everlastingly rejecting open-market operations in its monetary policy toolset. The present study analyzes the French monetary policy history by explaining why Bank of France had been so old-fashioned in monetary policymaking for too long time. Moreover, the article provides an explanation of the latter point by raising five major arguments of explanation : (1) the irrelevancy of the French interwar monetary reforms which enabled the Bank of France to conduct open-market operations per se; (2) the French conservatism throughout the insiders' view from the Bank of France leaders (not only governors and deputy governors, but also the General Council's members at the head of the French central bank); (3) the legacy of a metallist vision, embodied by Charles Rist, within the French economists of that time (4) the negative public opinion regarding open-market operations which were seen as being an inflationist public debt financing instrument and lastly (5) the unfair competition that occurred between the discounting operations and the open-market operations in the Bank of France's balance sheet.
\end{abstract}

Keywords: Open-market, Monetary policy, Central banking. N 14, B 22

*First draft. Do not cite without author's permission

${ }^{\dagger}$ Associate Professor in Economics, Université de Lyon, Lyon, F-69007, France ; CNRS, GATE Lyon Saint-Etienne, Université Jean Monnet, Saint-Etienne, F-42000, France 


\section{Introduction}

The 2008 crisis' epicenter put the stress on the money market mainly throughout two 'black swan' phenomenon (Taylor and Williams 2009) and the resulting upsurge in interest rates spreads (LIBOR-OIS spreads, EONIA-EURIBOR spreads and so on..). This financial crisis, inherited from the collapse of the mortgage credit (sub)market, put the spotlights on the necessity for central banks to intervene on the capital markets as well. In fact, the different types of unconventional or non-standard monetary policy measures taken by the $\mathrm{ECB}$ or the Fed restore more intensive open-market purchases so as to provide liquidity to the interbank money market (Giannone, Lenza, Pill, and Reichlin 2012) and to the economy as a whole. By so doing, central banks put aside, maybe temporarily, their traditional monetary neutrality which was the outcome of the 2004 Nobel Prizers works on inconsistency plans (Kydland and Prescott 1977). By playing their lender in last resort role, central banks favored their discretionary power -rather than their rule-like-behaviorby providing directly liquidities to private firms or States. All of that open interrogations and doubts on the monetary policy rule optimality as compared to a discretionary monetary policy. It seems that in the aftermath of financial crisis, the way we think and we speak about monetary policy changed. When external instability faces internal instability, thus monetary policy becomes more inclined to be considered as rule-like-behavior with due degree of discretionary power rather than a strict and automatic rule of conduct (Barbaroux 2013). Beyond this theoretical issue, there is a practical one that emerged: what status should be given to open-market (discretionary) purchases within monetary policy toolset? In such an inquiry, the French monetary history during interwar is enlightening.

As mentioned by Friedman in his last times, and also by several other great economists -such as Keynes, Wicksell, Cassel or the League of Nations Report- the French monetary policy had been unique during interwar ${ }^{1}$. In these interwar times, and beyond, the Bank of France was considered as

\footnotetext{
${ }^{1}$ In 2004, Friedman republished his seminal book on 'Monetary History of the United States (1867-1960)' (with A. Swartz). It was in that opportunity that those words were declared. Milton Friedman wrote as follows: "Reading the English translation of the memoirs of Emile Moureau (Governor of the Bank of France, 1926-1928) persuaded me that we understated the role of France in the international transmission of the contraction. [...] The international effects (regarding the great depression) were severe and the transmission rapid, not only because the gold exchange standard had rendered the international financial system more vulnerable to disturbances, but also because the United States did not follow gold-standard rules. Were I writing the sentence today, I would say: "because the United States and France did not follow gold-standard rules". (Friedman 2004: 349).
} 
being responsible of the Gold Standard collapse in the early 1931. Among the main reproach, the lack of open market procedure prevailed particularly from the English side.

By open market we mean the freedom given to the central bank to buy and sell short-term public assets, mainly Treasury bonds, on the money market so as to tighten or expand the monetary mass (banknotes) circulation while leading the short-term capital market. In that time, the open-market policy was a means of anticipating the discount claim from private banks to the bank of issue's windows. Contrary to the other major central banks, the Bank of France was late in setting up open market instrument within its toolset. From the first attempt in 1928, it took ten years to the Bank to move from a market follower position to a market maker one. The official monetary law that gave the Bank of France the full ability to manage open-market purchases was the one decided in 1938, June $17^{\text {th }}$. Before that, the previous monetary laws were only unsuccessful attempts in that direction. At first sight, the French rejection on open-market can be explained by the fact the Bank of France was already over-present within the French banking system and took care to whatever demands in liquidity (i.e discounting operations) from the private commercial banks. As the French economist Pierre Ricard wrote in an internal note for the Bank of France Economics Studies departments in 1929: "the fact that the Bank of France had always been ready, whatever the circumstances, to participate in the money market and to finance the private banking system prevented the country to set up an autonomous day to day money market." (Ricard, 1929) ${ }^{2}$. However, other reasons can be considered. This French passivity or conservatism is not the result of a random walk but it can be explained by both political and economical backgrounds. The aim of this paper -and the prevailing thesis defend- is to demonstrate to what extent the French rejection for setting up open-market device was mainly linked with a risk of loss in profitability for Bank of France. In that sense, the French monetary conservatism was no more than a rationale economic calculus.

The main question raised by the article is to what extent the Bank of France had an advantage to reject open-market for so long time? The main argument we want to test is twofold: (1) the open-market operations was seen as a substitute of the advance on liquidities to the French government, and (2) the open-market operations were seen as an unfair competition towards the discount operations that were the profit maximizing source of revenue for the Bank.

\footnotetext{
${ }^{2}$ Internal note from Bank of France archive, Reference Number: 13971994 03- 66.
} 
Five leading argument will be considered: (1) the irrelevancy of the monetary reforms to conduct open-market operations; (2) the French conservatism throughout the insiders' view from the Bank of France leaders (not only governors and deputy governors, but also the General Council's members at the head of the French central bank); (3) the legacy of a metallist vision, embodied by Charles Rist, within the French economists of that time and (4) the negative public opinion regarding open-market operations which were seen as being an inflationist and public debt instrument; and lastly (5) the unfair competition that occurred between the discounting operations and the openmarket operations in the Bank of France's balance sheet. By surveying the French newspapers in that time we can take into account the French public opinion concerning this new monetary policy strategy. For sure the above five arguments interacted one with each other so as to explain this French paradoxical conservatism.

After surveying the step by step setting of the open-market instrument within the French monetary policy toolset (Part I), the paper put the stress on the political and economical context in which the open-market debate occurred. We will focus on the way French economists and Bank of France's economists' saw the open-market purchases (Part II) mainly throughout the eyes of Rist and Quesnay. The last section will conclude (Part III). 


\section{The step by step setting of the open-market instrument}

The open-market procedure has a long history in France. This story is characterized by an everlasting rejection of this monetary policy device, mainly due to the French historical background. This point had strongly been debated among economists and central bank's advisors notably by Keynes under the Macmillan Commission in 1931. While Keynes and the international economic community encouraged open-market instrument in central bank's toolbox, the Bank of France saw it as inappropriate mainly because it was accused of being inflationist. Without any doubt, the 1936 year had been a turning point in the French monetary history. Firstly, the French franc is no longer fixed to a unique gold weight but rather to a flexible standard of gold weight. But,secondly, for the first time in its history, France started to manage a kind of open-market policy thanks to the July, $24^{\text {th }}$ law concerning the Bank of France status. From that time on, open-market procedure made a (big) step towards an official recognition among the monetary policy instruments event though the monetary device will only be effective in 1938 . The French open-market history was a winding road that needed four step, throughout four major monetary laws, before implementing open-market per se.

\subsection{Step 1: The monetary Convention from 1928, June, $25^{\text {th }}$ monetary law}

The open-market debate emerged in the early days of the French franc's stabilization after WWI when the group of economists in the Bank of France wondered what type of reforms the institution should conduct in order to expand the operational autonomy of the bank of issue (Blancheton 2001: 29). Thus, the Bank of France adopted fiscal and monetary regulations both in 1928 and 1929. Among those proposals for reform, the open- market operations emerged and created a real debate, if not to say a division, among the group of economists. Most of them were influenced by Charles Rist's monetary doctrines according to which open market was just a means to expand State's hunger for liquidity ${ }^{3}$. In that sense, open-market instrument was a source of inflation and public indebtedness.

It is right that the 1928 Poincaré law is a first step toward open-market

\footnotetext{
${ }^{3}$ Rist (1927) declared as follows in his book on deflation: 'the inflation was created in the form of the advances successively agreed by the Bank of France to the government.' (ibid: 60).
} 
operations. However, this step was only a half one. The 1928 stabilization law (known under the name of Poincaré Law) had been supplemented by a 1928 Convention voted in June 2nd between the Bank of France and the Redemption Fund (i.e Caisse d'amortissement). The Bank of France received 5.930 millions of French francs Redemption funds' assets as a counterpart of the Treasury bonds it discounted during the WW I and which had been used to finance foreign loans. Added to the discount rate policy, the Convention empowered the Bank of France to use a light version of open-market operations under two procedures:

1. Article 3, Specific direct channel:

The Bank of France could sell or buy, when the need arose, its assets from the Redemption Fund. Most of those assets were issued as a counterpart of the amount lost originated from the Russian loans ${ }^{4}$. More precisely, the 1928 Convention stated that the bank of issue could buy commercial papers with a minimum amount of 50000 French francs and the assets needed to have no more than 90 days validity. Due to this regulation, the first discounting company, called "Compagnie Parisienne de Réescompte", was created in order to proceed to these light version of open market operations.

2. Article 9, The traditional indirect channel:

The Bank of France had the authority to 'undertake, for the account of foreign Central Banks who had opened a current account in its books, the purchase of bills and short term securities [...] It (i.e the Bank of France) could discount those commercial papers, when those banks asked for it, from which it is allowed to guarantee until the end.'

In spite of those two new procedures, Bank of France did not use them mainly because it was costly. In fact, the Redemption fund's assets the Bank of France received were free of interests, meaning that in case of assets' sales, the Bank of France would have to pay the interests to the buyers.

Later on, France conducted three main reforms in 1929 that planned to develop the French monetary market:

\footnotetext{
${ }^{4}$ Russia had stopped paying back the loans agreed to by the Bank of France in 1917. So that, the newly created Fund was in charge of settling this debt that took the form of Russian Treasury bonds (those ended in 1945). This debt was not taken into account in the Bank of France balance sheet. As a counterpart, the Fund issued three months bonds (with free interest) that it gave to the Bank of France for the corresponding amount of the Russian loans.
} 
1. the Bank of France decided in 1929 to discount only franc denominated commercial papers;

2. the Bank of France authorized the discount of commercial papers for a seven days period (with the possibility of renewing it for a new five day period);

3. the French Bank Bill ('Banque Française d'acceptation') had been created $^{5}$.

Those last three reforms, and mainly the third one, were strategic. It was a means for France to escape from the British domination of London monetary markets. Before those reforms, huge amounts of money were transferred by French private banks to London's monetary markets which, then, influenced the exchange value of the franc. Private banks needed liquidity available in the short term that the monetary market in France did not have. The two opposite monetary policymaking strategy clearly appeared in that time. While France favored monetary conservatism, under discount rate management and a strict gold covering ratio, the Bank of England abandoned any strict cover ratio between the gold cash balances and the bank's deposits. In fact, the Bank of England freely intervened on the monetary market by selling or buying Treasury bonds so as to influence the amount of liquidity available without having to change its discount rate ${ }^{6}$.

\subsection{Step 2: Monetary regulation from 1935 February}

This new step started from the Bank of France new freedom to agree shortterm (i.e from 7 days to 30 days) advances backed on public assets, mainly Treasury bonds, with a maximum of two years maturity. This new regulation

\footnotetext{
${ }^{5}$ The creation of the French Bank Bill involved several French banks who cooperated both financially and institutionally. This institution was a bank of acceptance. A banking acceptance is an asset held by a bank that originally comes from the discount of a commercial paper (effet de commerce). The acceptances were used for the needs of international trade. It was a credit device that allowed an importer,via its local bank, to pay for its purchases, to the foreign bank of the exporter, through the circulation of this peculiar asset. When large amounts were concerned, this asset could then be exchanged with another bank who would find a means of investing its available bank deposits.

${ }^{6}$ We need to take into account that the British banking sector was quite different to that of France. The latter was self-centered, meaning strongly influenced by the Bank of France, and competition between private banks was moderate. However, the Bank of England was more of an "orchestra conductor" leading private deposit banks which had the power to create (bank) money through bank cheque circulation. The British banking sector was mainly directed through the discount market that empowered the Bank of England to act on the private banks and encourage/discourage credit within the economy.
} 
could have been really influential for the French liquidity markets since it opened a new source of liquidity funding -as compared to the traditional discounting operations- with a lower price. In fact, from that 1935 law, the private banks could ask short-term advances to the Bank of France by paying only the discount rate whereas the advances in liquidity from assets were traditionally provided, before that, at the broker loan rate which was higher than the discount one ${ }^{7}$. However, this type of money market was only an ersatz of a true open-market policy due to the small amount it provided to the banking system.

This light version of open-market instrument did not help the banking system by providing a new source of liquidity. However, beyond the small amount that had been traded, two main features separated this new source of liquidity with an open-market policy per se. Firstly, the operation was unilateral. It was only the commercial banks that could ask for liquidities to the Bank of France and neither the reverse. Secondly, the cost of the short-term advances depended on the discount rate and it could not freely fluctuate according to the vagaries on the money market. In that sense, it was still an administrative management of the liquidity market as opposed to a free market based management.

\subsection{Step 3: Monetary law from 1936 July, $24^{\text {th }}$ on the Bank of France official status}

Few months later with the last monetary regulations, France decided to make a new (small) step towards open-market practices by allowing the Bank of France to discount in an unlimited amount the Treasury floating debt assets which were due to a maximum of a three months period (Kritz, 1938: 143) ${ }^{8}$. However, this discounting operations was not authorized for the account of the French Treasury in order to prevent the hazard moral from political power to expand its deficit and debt. The 1936 July, $24^{\text {th }}$ law made a step toward open-market purchases -as opposed to the traditional discounting windowshowever, as in the previous case, those new source of liquidity were initiated by borrowers only, meaning the commercial banks, and neither by the Bank of France itself. As a consequence, the 1936 law did not fully set up open-

\footnotetext{
${ }^{7}$ The 'broker loan rate' is a specific rate of interest determined by the General Council within the Bank of France. This rate of interest was charged to private banks which borrowed liquidity, however, it could not be lower than the discount rate which represented a minimum rate in the French banking system.

${ }^{8}$ In that time in 1936, several European central banks had already experimented openmarket operations. Most of them were: the Bank of England, the Federal Reserve Bank of New York, the German Reichsbank and the Netherlands Central Bank.
} 
market in France as long as those liquidity funding operations will not result from both sides of the banking system.

In spite of the fact open-market was not put in practice yet, the 1936 monetary law called for strong reactions among the economists' community. At first sight, the new regulation was seen and understood, mainly by the press and general opinion, as an indirect help for the State's needs in liquidity. For that reason, Bank of France had to reacted by publishing an internal and private note from the Economics Studies Department from the General Secretary of the Bank. It published it in 1936, November $7^{\text {th }}$ so as to restore confidence on its official goals. The internal note pointed out that: "the changes we brought in the Bank of France status should not be understood as the sign of the forthcoming inflationary policy or an indirect help to the State." 9 . Moreover, the internal note recalled that "contrary to what had been published by the press and newspapers, the 1936 law does not authorized the Bank of France to buy or sell government's securities, that is to say to act on long-term interest rates and on the evolution of the stock markets' values." (ibid). In other words, the discount rate management with a unique rate leading the market still prevailed.

\subsection{Step 4: The 1937 July Law and the Law decree from 1938 June, $17^{\text {th }}$}

It was only from that stage that open-market entered in the French monetary policy. It was the law decree dated back from 1938 June, $17^{\text {th }}$ that recognized open-market practices among the Bank of France official status ${ }^{10}$. According to this new regulation, the French monetary policy could manage open-market operations defined as follows:

"Art.1: In order to act on the credit volume and to regularize the money market, Bank of France is allowed to buy and sell, into the limited amount and conditions decided by the General Council, on the money market (called in France the "free market") public negotiable short-term assets and private assets which are officially admitted to be discounted.".

Official Journal from 1938, June $29^{\text {th }}$, p. 7443.

Other texts and articles fixed the conditions according to which openmarket should be conducted ${ }^{11}$ :

\footnotetext{
${ }^{9}$ Bank of France archive, Reference Number: 10692008 03- 17

${ }^{10}$ Bank of France archive, Reference Number: 13602007 01-45

${ }^{11}$ July, $7^{\text {th }}$, 1938, Reference number: 10692008 03-16
} 
- Art. 1: the assets which are concerned by open-market operations are: the Treasury bonds, the bonds from the National Defense, the assets from the French National Railway Company (called $S N C F$ ) and banking acceptances;

- Art. 2 and 3: each operation should reach a minimum amount of 100000 French francs (unless for the banking acceptances which could be traded for a 50000 French francs amount) with a maximum of two years maturity term;

- Art. 8: the open-market operations should not amount to more than $8 \%$ of the gold reserves in the Bank of France.

The article 8 was mainly motivated by the desire to give a force of opposition to the Bank. In fact, the content of the article 8 had given birth to strong and long discussions between the General Council members within the Bank of France. Most of them were worried about the possibility given to the Treasury to find in the open-market policy a new source of funding. These strong discussions were summarized in thirteen pages within the report from the General Council. A confidential note within the Economic Studies Department of the Bank gave the content of these discussions ${ }^{12}$. Among the proposition, two prevailed: (1) to limit the open-market purchases to the amount of a few asset items (such as the amount of private deposits or the amount of the current accounts of the Stabilization Funds and the Foreign Exchange Supporting Fund) of the balance sheet of the Bank of France; (2) to limit the open-market purchases to the amount of a fixed ratio with the gold reserves or a fixed ratio with the asset portfolio and advances in liquidity provided.

In practice, the article 8 lasted only one year. The open-market roof had quickly been exceeded from 1939. As a consequence, an extraordinary General Council meeting had been organized in February, $29^{\text {th }} 1940$ so as to abrogate it. Thus, the article 8 had been canceled and substituted in July, 1939 by the following article: "the amount of the (open-market) operations should never exceed ten billion of French francs." 13. Few months later, this official roof quickly changed once more and amounted to fifteen billions of French francs ${ }^{14}$. From 1939 to 1968 the amount of the roof had always been increased by successive decrees. The table (1) in appendix summarizes

\footnotetext{
${ }^{12}$ Bank of France Archive, Reference Number: 10692008 07- 17

${ }^{13}$ Statement from the extraordinary session of the Bank of France General Council from February, 29 $9^{\text {th }}$, Reference Number: 10692008 03-16.

${ }^{14}$ Bank of France General Council from 1940 October, 30 ${ }^{t h}$, Reference Number: 1069 2008 03-16
} 
the successive maximum amounts authorized by the General Council for the open-market purchases. It was only in 1968 that the maximum amount on open-market purchases had been canceled.

From that period, we have to note that Bank of France could act not only on the monetary market but also on the financial one. In fact, in 1937, France decided as well to create the French governmental securities support Fund (Fond de soutien des rentes) which enabled it to intervene on long term market, mainly on the governmental stocks market. This new monetary institution was granted by a seven billion of French franc capital resulting from the profit emanating from the reevaluation of the gold stocks in the Bank of France when French franc had been (re)defined by a new par, i.e one French franc valued $43 \mathrm{mg}$. of gold. The newly created Fund aimed at buying and selling long term public debt assets or whatever other assets -both in short and long terms- from the French Treasury.

This laws survey on open-market practices demonstrates us to what extent France was conservative in monetary field. Bank of France never abandoned its old fashioned way of speaking and thinking monetary policy, mainly by way of quantitative management of monetary policy even for open-market interventions. As it appeared among the economists' views in that time, and particularly, among the French public opinion: open-market should be seen as a complementary tool but neither as the leading instrument of the monetary circulation. Monetary policy was- and had always been- a discount rate management that should regulate the monetary mass circulation (mainly banknotes issue). However, during interwar and in times of inconvertibility such way of thinking is disconnecting from the new way economics functioned (i.e huge issue of public debt assets and wide fluctuations of the exchange rates). 


\section{The French opinion regarding open-market operations}

Before the 1938 year, the French (interbank) monetary market did not practically existed per se in the extent it was downgraduated as a market outside the scope of the Bank of France and the whole French economy as well. In fact, the French monetary market was labelled as the "outside banking market" (marché hors banque) or the "free market" due to its lack of specific regulations and the lack of influence from Bank of France. Moreover, for a considerable long period, the French interbank market was self- centered in Paris and it was no more than a market for acceptances assets ${ }^{15}$. Such state of affairs well illustrates the absence of consideration for the interbank money market until the 1938 monetary law and within monetary policy toolset. This french public opinion on open-market was driven by both the schizophrenia for gold and the great influence of metallist ideas with its French spokesman Charles Rist. However, other voices emerged so as to give a new youthfulness to the French monetary policy. Two clans emerged: the insiders group which gathered the Charles Rist and the Bank of France economists' within the General Council and the outsiders led by Pierre Quesnay and the Governor Moreau in place. The French public opinion -such as it appeared in the newspapers we collected from the Bank of France archive- was mainly in favor of the insiders group.

\subsection{The French economists' views on open-market}

Contrary to the Swedish economists who were well known for their intensive involvement in the writing for periodicals, newspapers or public conference (Carlson and Jonung 2005), the French ones were the opposite. As mentioned by Fontana (2000), French economists were not really popular in the early twentieth century. They suffered from a lack of international recognition due to their (over) involvement in political and institutional issues. For instance, the French economists of the late eighteenth century were given abroad the negative label the 'Parisian group' in allusion to their influence in the restrictive area of Paris' institutions. In his survey of the French economic tradition, Schumpeter (1954) shared this opinion by claiming that: "their main interest was not the 'purely scientific aspect of economy' but business

\footnotetext{
${ }^{15}$ Those assets were used for the needs of international trade. It was a credit device that allowed an importer, via its local bank, to pay for its purchases, to the foreign bank of the exporter, through the circulation of this peculiar asset. When large amounts were concerned, this asset could then be exchanged with another bank who would find a means of investing its available bank deposits.
} 
and political practice" (Fontana 2000: 236). However, this poor reputation of French economists changed at the beginning of the twentieth century with an emerging younger generation. They were the opposite to the old ones as they had reached an international stance through their theoretical works or their international influence among leading institutions. Of this new generation, the most influential were Charles Rist, André Gide, Bertrand Nogaro and Albert Aftalion. Only a few of the old generation were a part of this group, such as Jacques Rueff ${ }^{16}$. Charles Rist was withount any doubt the most influential among them in the French monetary thought.

\subsubsection{Charles Rist and the Bank of France: the insiders views}

The leading ideas that open-market operations were a source of inflationary process was clearly inherited from Rist's metallist dogma. The later ideas prevailed for a long time within the Bank of France corridors. During the interwar period, the influence exerted by Charles Rist (1874-1955), even after his deputy-governor mandate, is not to be questioned. As Dehem (Dehem: 206) wrote "Rist provides the key to understanding the French position in monetary matters as opposed to the typical Anglo-American stance in the past 60 years". Rist got the particularity of being influential both in the academic circle and the institutional circle of the Bank of France. He was a monetary expert in several foreign countries such as Portugal or Romania while being member of the board of experts in 1926 that worked on the stabilization of the franc. He had been second-deputy-governor in the Bank of France between 1926 and 1929.

Rist was a representative in France of the 'metallist' dogma that had already prevailed in the previous century (with the collaboration of Jacques Rueff). Yet, by updating Took's position on paper-money, Rist distinguished himself from the traditional metallist embodied in the Ricardian theory. For this reason, he was labelled as a 'dissident metallist' ${ }^{17}$. The quotation from Dehem was an explicit allusion to the prevalence of metallism in France through Rist. According to the metallists' views, money value does not exist in itself, it is the metal, whether gold, silver or copper, that gave value to money (Rist 1938). In terms of function, Rist saw money as being es-

\footnotetext{
${ }^{16}$ Jacques Rueff was considered to be a member of the 'Paris group' even though the relationships with the younger generation, mainly with Rist, were more relevant. He was a pupil of a well known French Paris Group economist: Clement Colson

${ }^{17} \mathrm{It}$ is interesting to note that Schumpeter (1954) made another distinction between two forms of metallism: a theoretical metallism and a practical metallism (ibid: 403-404). The idea was to demonstrate that metallism could still be useful for the conduct of monetary policy whilst being out of date to define money.
} 
sentially defined by its store of value function which is seen as 'the most important function, and the one which is probably at the origin of all the others' (ibid: 347-348). The store of value function is seen as an 'insurance against the uncertainties of the future' (ibid). Rist rejected all forms of inflation and deflation in the economy. According to his own book on deflation, Rist (1927) defined it as a permanent 'reduction in the instruments of circulation' originating from 'the issue of forced currency bank notes or from State paper-money.' (ibid:1). Thus, the idea of a monetary policy that gave due place to open-market regulation in spite of a pure discount rate management was not welcomed. Rist's monetary theory is quite well-known for its fundamental distinction between money, meaning gold money, and credit or fiduciary money, meaning bank notes or bank deposits. To Rist, only the former deserved the label of 'money' whereas the latter was just a substitute for money that helped monetary circulation. They were just an instrument of payment but they were not money per se. As a consequence, monetary policy should only be concerned with gold accumulation so as to ensure the convertibility of notes into gold. These distinction had practical consequences for monetary policymaking.

In fact, Rist favored a monetary policy based on a discount rate management in line with the Classical lessons of the monetary orthodoxy. By emphasizing the store of value function, Rist was opposed to authors of his time who supported non-metallic currency ideas such as Knut Wicksell, John Law or even John Maynard Keynes. He rejected Keynes (and Cassel) understanding on the interwar monetary crisis and depression which supported the idea of a managed money and their explanation of inflation disconnected from the Quantity Theory (Bellet, Gloria-Palermo, and Zouache 2004). For instance, Wicksell's thesis according to which a mismatch between the natural rate of interest and the effective rate of interest (i.e discount rate) is not seen by Rist as a valuable explanation ${ }^{18}$. We found a critical lecture note on Wicksell's theory ${ }^{19}$ that Rist gave in the thirties at the university for doctoral studies when he taught monetary crisis. The main criticism relied on the doubtful existence on a natural rate of interest in Wicksell theoretical corpus.

When the discussion on open-market operations started, Rist was at that time second deputy governor of the Bank of France (1926-1929). He was strongly opposed to any form of a market regulation in monetary issues such as the monetary market in Paris which tried to provide, and regulate, the

\footnotetext{
${ }^{18}$ It was the difficulty to define and verify this hypothetical natural rate of interest that motivated Rist to reject Wicksell's thesis.

${ }^{19}$ Bank of France archive, Reference number: 10372006 03-12.
} 
liquidity needed by the private commercial banks. As he claimed, it would be prejudicial to use open market procedure because it would imply that 'the bank behaves not only as an anvil but as a hammer' (?: 442). In other words, Rist questioned the counter-cycle policy that banks of issue could manage with the help of open-market operations. Thus, the Bank of France would take the risk to loose its "operational autonomy" such as defined by Blancheton (2001). This active policy switches the domestic market off from the international one. By so doing, it could influence the level of liquidity available on the international monetary market so as to offset the opposite conjuncture in its domestic credit market (via the fluctuation of the discount rate or the amount of gold cash reserves).

Rist opinion can be explained for two reasons. Firstly, the experience given by history is the main proof that Rist claimed to justify his thoughts. Rist, and most of the official members of the Bank of France, had kept in mind a negative background concerning the open-market. They were convinced that this instrument was at the origin of both inflation and crisis as demonstrated by Mouré (1998). They made the confusion between openmarket practices and the advances in liquidity system that prevailed in France during interwar. As he declared in his book on deflation in 1927, open market was just a means to expand State's hunger for liquidity:

Inflation was created in the form of the advances successively agreed by the Bank of France to the government.

Rist, 1927: 60

Secondly, Rist considered that the French franc devaluation following WW I was exclusively the result of "bad money" creation emerging from the huge advances in liquidity that Bank of France provided to the French Treasury for reconstruction purposes.

Rist had been strongly questioned by Schumpeter for his misunderstanding of the credit mechanism. Maybe it was for that reason that French economists at that time were not well-known abroad. In the monetary field, the French school was really conservative. So that, the increasing development of credit tools and the de-materialized form of money was not seriously taken into account in France. By contrast, the Swedish school, with its chief and spokesman Knut Wicksell, was forerunning by elaborating a modern theory which tried to 'restate a Quantity theory in a credittheoretical term' (Trautwein and Boianovsky 2001: 500) ${ }^{20}$. However, some voices emerged among the new generation of economists, namely Nogaro,

\footnotetext{
${ }^{20}$ The label Swedish School was not given to Wicksell but to his followers such as Gunnar Myrdal, Erik Lindahl and Gustav Cassel to name but a few.
} 
Aftalion and Simiand. They had in common two beliefs: first, the idea that Quantity theory was not relevant, particularly when it is applied to the French case, and, second, they started to admit that credit can be seen as money. The latter point was a real betrayal regarding Rist influence on the French economic thought. However, the position defended by Pierre Quesnay and the Governor Moreau was more in agreement with this new monetary thought.

\subsubsection{Governor Moreau and Pierre Quesnay: the outsiders views}

Contrary to Rist's views, the Governor Moreau were enthusiastic concerning the measures taken in direction of open-market in 1928 by the Stabilization Law from Poincaré ${ }^{21}$. Governor Moreau expected to take advantage of the new directives to restore the small money market of Paris. Governor Moreau, supported by the economist Pierre Quesnay, considered that the 1928 monetary law was a good opportunity to restore as well the French supremacy on the capital market and mainly against the Bank of England domination. Moreau and Quesnay were enthusiastic concerning the possibility offered by the article 3 of the 1928 law which opened a source for open-market operations. By this way, Bank of France could find a productive use of its huge metallic cash reserves while developing a new monetary policymaking in line with the one of the major central banks.

After the Poincaré stabilization law in 1928, one of the primary policy decision that Governor Moreau took concerned the monetary market of Paris which was no more than a market for acceptances assets. The latter was a kind of inter-banking market in which the Bank of France with private commercial banks, business banks, credit company and others banks (such as the 'maisons privées de haute banque') could exchange their bank debts. This short-term market referred explicitly to Warburg's concept of "circulating credit". The restoration of this interbank market was not insane owing to the huge foreign reserves held by the Bank of France in that time. By using it, Bank of France could have brought liquidity without having to act on the discount rate. The later point was a major cause of disagreement with Rist's view. From the private correspondence we found in the archives of the Bank of France between the Minister of Finances, Henry Chéron, and Governor Moreau, we can claim that Moreau got the support of the French minister of Finance in that time ${ }^{22}$. However, this illusion quickly disappeared under

\footnotetext{
${ }^{21}$ It should be noted that in the early days, Governor Moreau was not really enthusiastic with open-market's new freedom. It took time for Quesnay to convince him (Moreau 1954).

${ }^{22}$ From Chéron to Moreau "You know the importance that I grant to the creation of a big international credit market in Paris. For that reason I will not neglect anything that
} 
Rist's supremacy and the irrelevancy of the 1928 monetary law as we saw beforehand. In 1930, Governor Moreau resigned from his official function as governor in September. In his farewell speech, he publicly mentioned the failure to conduct open market as one of the major reasons for his decision (Moreau 1954). This episode illustrates the power of the insiders views within the Bank of France throughout the "Conseil des Régents" which led the monetary decisions within Bank of France ${ }^{23}$.

Beyond that, two reasons can be added to explain Moreau and Quesnay's failure: (1) most of the settlement of the public debt had been settled (with the help of the Caisse d'amortissement) in 1928 and more importantly (2) there was a lack of cooperation between private banks. On this subject, Sir R.G Conolly, when criticizing the French behavior during the 1931 Sterling crisis, gave a good synthesis on the French banking behavior :

"the Parisian banks would have preferred to slit their own throats rather than cooperate on the market."

in Mouré, 1998: 222

\subsubsection{The "Rist vs Quesnay" controversy}

Quesnay and Rist opposition was a prime illustration regarding the two opposite views on monetary policymaking which faced one with each other in France during interwar time. Before becoming the General Manager of the Bank for International Settlement between 1930 and 1937, Quesnay was the Director of the Economic Studies department in the Bank of France (1926 to 1930). Thanks to Rist, Quesnay participated, as a secretary, on the French Board of Experts that worked on the Stabilization policy in 1926. He wrote a few articles during, the main one dealt with banking regulation (Quesnay,1932).

Quesnay publicly entered into conflict with Rist at the time of discussion on the 1928 monetary law. We found in the archive of the Bank of France two internal notes and correspondence between them. Charles Rist wrote, first, a note on August, $28^{\text {th }} 1928$ on the possibility for Bank of France to intervene on the 'outside banking market' (marché hors- banque). Without any surprise, Rist was totally opposed to any open-market instrument for

is in my power to succeed as soon as possible in the creation of it." (Archives Department of the Bank of France, Reference number: 1060-2004-01-308).

${ }^{23}$ Without changing its duties, the "Board of Regents" within the Bank of France changed its name from 1936 and became the "General Council" of the Bank. 
Bank of France toolset owing to the inflation risk. Rist demonstration relied on two major points: first open-market is ineffective and second open market is also useless. On the first point, Rist denounced the upsurge of inflation that could be consecutive to any type of Treasury bonds purchases by Bank of France. Moreover, the regulation of the monetary mass by way of openmarket purchases will be ineffective since the quantity that Bank of France could withdraw will be limited to the quantity it sold previously on this interbank market. Moreover, the open-market purchases will concern only a few banks with a specific interest rate which was contradictory with Bank of France status. On the second point, Rist demonstrated thoroughly that open-market purchases would have reach the same results as the Bank of France could have reached with its discount rate management.

Two days later, Quesnay wrote a note as an answer to Rist's one. He answered scrupulously to any paragraph that Rist wrote. Concerning the inflation risk, Quesnay underlined Rist's bad faith by recalling that inflation would emerge from open-market purchases only if an over-issue of money was already present. In case of a normal use of open-market, the purchase of public assets will not be prejudicial to the French banking sector and the French economy as a whole. All along the article, Quesnay's answers particularly insisted on the necessity for Bank of France to update its monetary policymaking. While most of the major central banks, meaning the BoE, the Reichsbank and the Fed, favored open-market regulation of the quantity of money, France went it alone by favoring its old discount rate policy with its administrative rules and procedures. The position of Pierre Quesnay was not surprising since he had always been a defender of an international cooperation between nations owing to the peculiar inter-war context (Quesnay 1932). All of this justifies the gathering of worldwide strength in order to act in the same way. On this subject, Quesnay declared in August $16^{\text {th }}$ 1928:

If we restrict ourselves to a discount rate policy while the other Central Banks focus on an active management of the currency, we will bring about prejudicial fluctuations in the capital market; and I am convinced that far from participating in the regulation of the international credit market, we will disturb it.

Mouré 1998: 226

The Rist vs Quesnay struggle is illustrating of two opposite way of considering monetary policy. While Rist defended the traditional Classical metalist views on money, Quesnay was representative of an emerging new generation of French economists disconnecting with the Quantity theory explanation of inflation and in agreement with the new type of credit money that developed 
since the beginning of the $20^{t h}$ century. The most interesting point is that the Rist vs Quesnay conflict can be understood under the famous rule vs discretion debate inherited from Simons (1936). Rist favored an automatic central bank's behavior driven by the exchange rate fluctuations, the gold points and the discount rate management. In fact, the neuralgic point in Rist's position turned around the discretionary power that would be given into the hands of the Bank of France to decide whether it will buy or sell the short-term public assets:

"The Bank will spontaneously take the decision to provide or withdraw liquidity into the market. It expect the demands instead of wait for them. [...] The crucial point is to decide according to which principles and when the bank will judge as legitimate the liquidity provision to a market which did not ask for it."

Rist Internal Note, 1928: 2-324

By contrast, Quesnay was a defender of a new freedom of action for Bank of France when it has to take monetary policy decisions:

"The main feature of the open-market system is to let the Bank to be free of action."

Quesnay Internal Note, 1928: $2^{25}$

Outside, the major central banks supported Moreau and Quesnay's views. In fact, during the 1931 Sterling crisis episode, the Bank of England, via Sir Leith-Ross, asked the Bank of France to set up an open-market procedure which could allow the injection of liquidity through the purchase of bonds or other financial assets. Unsurprisingly, the new French governor, Clément Moret -who followed Moreau's mandate- also refused the British proposal once more. The immediate answer was that 'the open-market operations will bring illegitimate profit to the bank' (...) and this kind of policy-making was an error in principle since it relied upon 'financing the purchases of securities thanks to the note issue' (Mouré 1998: 148). In agreement with Rist's views, open-market was seen in that time as a sterilization process with due inflationary risks.

The 1944 League of Nations' report written by Nurkse is a good synthesis of the way France was judged by the other countries in this open-market

\footnotetext{
${ }^{24}$ Bank of France archive, Reference number: 10692008 03- 17.

${ }^{25}$ Bank of France archive, Reference number: 10692008 03- 17.
} 
failure episode. In his report Nurkse severely criticized the French policy during the inter-war period. More than a criticism it was a condemnation, he accused France of being widely responsible for the collapse of the gold standard. If France "played an important role in the breakdown of the system"(ibid: 39) it was due to its 1928 monetary Law. In fact, this law "decided to take nothing but gold in settlement for the enormous surplus occurring from the repatriation of capital and from the current balance of payment" (ibid). Consequently, and we already know the end of the story, a large part of the British and American gold went in direction of France which forced the other countries to accept a gold drain in their reserves (and then brought about a depression effect on the other countries, particularly England which later abandoned its gold pound parity). In this end of story, France had its full part of responsibility, as claimed by Friedman in 2004. As a consequence, when Bank of France was granted with the open-market instrument, the decision was welcomed abroad. For instance, the Royal Bank of Canada published an article ${ }^{26}$ in September 1938 so as to congratulate the new monetary directives set-up in France. While mentioning that the French monetary policy had always been thought to serve the needs of the commerce, mainly the small shops, the Bank of Canada saw in the 1938 reform the new possibility for the major central banks to cooperate. In this subject, the article clearly denounced the "exceptional rigidity of the French credit market" that occurred during the 1931 British Sterling crisis. The main criticism relied on the enormous gold sterile reserves held by the Bank of France which refused to use it to the benefit of the international credit market. The Canadian reaction was in agreement with the thesis defended by Pierre Quesnay who supported open-market policy in 1928 due to the necessity to cooperate with the major central banks which already got open-market instrument in their toolset.

\subsection{The French opinion on open-market}

From 1938, the reaction in newspapers was numerous not only in France but in foreign newspaper as well. Most of the newspaper articles gave the same negative opinion regarding the new open-market instrument: it will be a major source of inflation. The best way to express such public opinion is taken from the French newspaper 'Les Nouvelles Economiques et Financières' ${ }^{27}$ dated back from July $8^{\text {th }} 1938$ with the following headlines: Towards Dictatorship and War. On the road to "Open-market": open market?... open for

\footnotetext{
${ }^{26}$ Bank of France archive, Reference number: 1069200807 -17.

${ }^{27}$ Bank of France archive, Reference Number
} 
whom? To inflation ?28.

Among the many articles written in this corner-stone period, several ideas and opinion emerged in the press:

- The definition of the open-market purchases:

Many of the articles took care to give a more or less relevant definition of 'open-market purchases' since this type of central banks intervention was not widespread in France. We have to keep in mind that the French monetary policy system was an administrative management of the money issue with a long strained relationship history between the Bank of France and the French Treasury (Blancheton 2001). Thus, when the idea of a free intervention for Bank of France appeared, it was a real revolution in the French monetary system. Until now, most of the Bank of France decisions were made under the pressure -or the full authority- of the French Treasury for the State financing purpose. The first task was to translate "open-market" for French people who were not ready -even nowadays- to use English words in their day-to-day vocabulary. Among most of the newspapers, the 'open-market policy' expression was translated by 'free market operations policy' expression. This way of translating the expression "open-market" contains an ulterior motive by putting the stress on the word 'free' meaning that the Bank of France would be free to decide when it has to sell or buy short-term public assets; but also meaning that Bank of France will loose its control to the benefit of the emerging free interbank money market. Some of the articles published in this period mentioned that the open-market purchases will be limited to a maximum amount so as to prevent the French Treasury to use it as a source of funding.

We have to note that in most of the headlines chosen by the newspapers in 1938, the word inflation has always been associated with openmarket which encouraged French public opinion to see open-market purchases as the new monetary devil as opposed to the previous one (i.e the system of State's advances in liquidity by the Bank of France).

- Open market as a new type of inflation instrument to the benefit of the State:

In that time of WW I reconstruction, the French Treasury tried to restore a new balance of the State account, particularly after the Stabilization law -known under the name of Poincaré Law- in 1928. As a consequence, the French public opinion saw open-market instrument

\footnotetext{
${ }^{28}$ The translation is mine. The original title was: "Sur la route de l' "open-market": Open market ?... Marché ouvert. Ouvert à quoi ? A l'inflation ?".
} 
as a source of funding for the State. This is the point that French newspaper supported in most of the case.

The French newspaper -called L'Intransigeant- presented the 1938 monetary decree-law as a complementary regulation of the ones which restored the financial reconstruction of the country decided by the left wing coalition power in place from 1936. By mentioning that the French Treasury needed 40 billions of French francs in 1938 to restore the financial situation of the country, the open-market new freedom was seen as a State financing new device. Without any surprise, the extreme left wing newspaper -called l'Humanité- did the same. the newspaper gave an oriented definition of the open-market purchases. The article dealt only with the inflation risk linked with open-market instrument without mentioning that those assets purchases will be quantitatively limited. Open-market purchases were no more than a new way to monetize the huge public debt as the French government did since the end of WW I and during this reconstruction period. By monetizing the public debt, the newspaper makes the reference with the advances in liquidity system that existed till 1928 and which had been restored by a new Convention in 1936 (June $18^{\text {th }}$ ). After 1936, not only were the temporary advances re-established, but they were also assured to be interest-free for the credit service. In that sense, open- market assets were seen as a modern type of advances in liquidity for the account of the French Treasury with a higher risk. Since the advances in liquidity had been the major source of inflation after WW I, the open-market assets were seen as the same monetary devil. Each time inflation increased, it was the fixed income people that will suffer the most. The newspaper l'Humanité saw inflation as an indirect type of income tax in a context in which the fiscal weight was already too heavy. The French newspaper (Aux écoutes de la Finance from July, $1^{\text {st }} 1938$ belongs to the same faction as the l'Humanité newspaper by writing in its headlines "the return of the floating debt".

However, the most interesting point of view is to be found in the 'Orientation économique, industrielle et financière newspaper dated back from July, $2^{\text {th }}$ 1938. The open-market instrument was compared to the dark French episode of the 'assignats' of the $18^{\text {th }}$ century ${ }^{29}$. From this

${ }^{29}$ The 'assignats' were paper money issued by the National Constitutional Assembly in France during the French Revolution in $18^{\text {th }}$ century. Those were issued after the confiscation of church properties in 1790 following the government's bankruptcy. The government thought that the financial problems could be solved by printing certificates representing the value of church properties. Assignats were used to successfully absorb a 
episode, the article put the stress on the inflation risk driven by the State's hanger for liquidity in these times of huge public debt. Moreover, the comparison draw the attention on the loose of control risk for Bank of France since there was no control over the amount of assignats to be printed in that time. The assignats' episode brought about sharp inflation and a widespread mistrust towards dematerialized money and assets or towards whatever new type of money and assets disconnecting from gold.

As a first step conclusion, open-market instrument was not welcomed by the French opinion, mainly due to the way the French newspaper define it. We have to keep in mind that the interwar period is peculiar. History mattered for French people. They did not forget the last fifteen years of currency disconnecting from gold, the 1928 Stabilization law that officially recognized the devaluation of the French francs and the huge public debt that strangled the whole country after WW I particularly due to an over-use of temporary advances instrument by the French Treasury. The open-market instrument was regarded as a possible threat for the Bank of France ability to control not only the monetary mass circulation, meaning inflation, but also to surround the State's hanger for liquidity.

significant portion of the national debt as they were accepted as legitimate payment by domestic and international creditors. However, their excessive reissuing and the confusion with general currency in circulation caused hyper-inflation. Originally meant as bonds, Assignats evolved into a currency used as legal tender. As there was no control over the amount to be printed, the value of the Assignats exceeded that of the confiscated properties. This caused massive hyper-inflation. At the beginning of 1792, the Assignats had lost most of their nominal value. In 1796, the Directoire issued 'Mandats', a currency in the form of land warrants to replace the Assignats, although these too quickly failed. 


\section{The unfair competition thesis: Bank of France's discounting operations vs open-market oper- ations}

'The (bank) metamorphosis from their involvement in commercial banking, as a competitive, profit-maximizing bank among many, to a non-competitive non-profit-maximizing role that marked the true emergence and development of proper Central Banking." 30

Goodhart 1988: 9

The open-market operations were seen as a substitute for the advance on liquidities to the French government. As the quotation written by Goodhart teaches us, profitability mattered more for Bank of France than in the other central banks (Goodhart 1988). As a consequence, a second hypothesis can be opened: Bank of France everlastingly refused open-market owing to the fact those operations were prejudicial for the profit maximizing purpose of the Bank. This unfair competition thesis could explain why the French conservatism prevailed for a (too) long time. In that sense, the conservatism was in reality a French hanger for profit at the expense of the central banking duties.

\subsection{Did the open-market assets being a source of fund- ing for the Treasury?}

Among the major reason of disapproval, the inflationary risk originated from excessive Treasury bonds issue -and bought by the Bank of France- prevailed. France got increasing needs in liquidity due to the floating debt burden inherited from WW I (see figure 3 in Appendix part) ${ }^{31}$. As showed by the figure (3) in the appendix part, the French debt was mostly an internal debt originated from huge amount of public assets' issue (Dulles 1929). This type of floating debt was seen as the most dangerous because of the fact it matured early but also because of its size. It was seen as inflationary because those assets were issued at a lower and fixed interest rate that would prevail.The money issue -mainly under the form of advances and note issue-

\footnotetext{
${ }^{30}$ The word in brackets is mine

${ }^{31}$ The floating debt refers to the part of the public debt which is not consolidated by medium and long term assets. In other words, it is the total amount of public loans in the form of Treasury bonds, advances from Bank of France or specific war bonds called "Bons de la Défense Nationale".
} 
increased which created in its turn an inflationary process (see figure (1) in the Appendix part) in a Wicksellian kind of way, i.e cumulative fashion way (Wicksell 1898).

Bank of France agreed to the French Treasury different types of advances in liquidity according the signature of several Conventions. From 1938 to 1951 no more than four different Conventions had been granted by law so as to authorized the Bank of France to provide huge amount of provisory advances to the French Treasury and for free. We have to note that in these hard times of interwar periods, the liquidity was missing and particularly after WW II. For that reason, the amount of advances in liquidity to the French Treasury strongly raised after WW II. The system of advances featured the French monetary machinery. For a very short time (between 1928 to 1936), Bank of France ended its duty as the official financial manager of the State. As we already saw, the advances in liquidity were mainly criticized since they were the main roots for inflation as Rist always claimed. As a consequence, Bank of France's member of the General Council took particular care on this item. The General Council published a report on the November, $23^{\text {th }} 1939$ session on that issue ${ }^{32}$. The Permanent Comity of the Bank made this declaration within the session:

The money market is not able to satisfy the huge demand on liquidity by the State. We have the duty to prevent the risk of a monetary tightening; and since the required amount served to reimburse us, it is thus that we make an effort. It is preferable that this effort take place by way of the"negotiable assets in France"item rather than the "advances in liquidity" item.

General Council Session, November, 23 ${ }^{\text {th }}$ 1939: 2

The report on this session clearly mentioned that the stability of the "advances in liquidity" item is a crucial element so as to assure public opinion confidence. It is right that French opinion took peculiar care on this item due to the previous period habits in which the Treasury made an intensive use of this source of funding in the previous years (mainly 1918-1928). As a consequence, inflation dramatically raised up (see figure (1) in the Appendix part) (Maddisson 1981). We have to note that the 1939 year was featured by an increasing need in liquidity which explained why the portfolio asset of the Bank of France increased dramatically from 670 millions of French francs in september 1938, $14^{\text {th }}$ to 4.654 millions of French francs in november, $23^{\text {th }}$ 1939. As a consequence, the evolution of the "advances in liquidity" item in

\footnotetext{
${ }^{32}$ Bank of France archive, Reference Number: 1069200803 -16.
} 
the Bank of France balance sheet should be analyzed at the same time as the "negotiable assets bought in France" item. The figure (??) gathers the evolution of open-market purchases, from 1938 to 1951, with the evolution of the different types of advances Bank of France provided to the State.

According to the insiders concerns, we could have expected that the " $n e$ gotiable assets bought in France" item increased while the "advances in liquidity' item decreased after 1938. As we can see in figure (??), both items increased during this period so as to serve the needs of the State. We have to remember that the system of advances in liquidity, such as it existed before 1928, had been fully restored by the 1938 law. After 1936, not only were the temporary advances service were re-established but it was also assured to be interest-free for the credit service.

As Rist and the insiders' clan worried, open market became an important monetary policy tool but only after WW II. However, the use of the advances in liquidity agreed by the Bank of France did not ended as a counterpart. On the contrary, both source of fundings increased after WW II, mainly due to the reconstruction needs. This feature is typical of the French bad habits which never stopped using advances in liquidity provided by Bank of France. This facility was seen as the price to pay for the privilege of issue that the Bank of France owed until 1945 and which had been renewed after the Nationalization of the Bank at that date.

\subsection{Open-market purchases vs discounting operations: an unfair competition?}

The open-market purchases of the Bank of France were ranked in its balance sheet in the 'negotiable assets bought in France' item. The later gathered mostly, Treasury bonds, National Defense bonds, Commercial papers from the National Railway Company (SNCF) and banking acceptances. When Rist considered the possibility or not to use open-market among the official monetary policy toolset of the Bank of France, he clearly pointed out the risk of a loss in profitability that those purchases will bring about. In fact, not only open-market assets would be preferred to discountable commercial papers when the banks would be in search for liquidity funds; but also the open-market activity will be made at different level of interest rates while the discounting activities are paid at a fixed price decided by the General Council of the Bank. The later structural transformation in policymaking would imply a loss of monetary control to the benefits of the money market. The last point was clearly in opposition with the old French way of policymaking according to which Bank of France should serve the needs of commerce to 
every firms and banks and particularly with a unique and quite fixed discount rate. By contrast, the Bank of England, for instance, fixed different types of discount rates which had always been put into question by French policymakers and economists. Several reports from the General Council of the Bank criticized en passant the British policy of adjudication at different level of interest rates.

A confidential internal note from the Economic Department Studies of the Bank of France in August, $19^{\text {th }}$ 1939, opened the profitability debate as follows:

It is noteworthy that every type of intervention on this market is, by nature, a possible risk to the Bank which would be, according to its size, incompatible with the normal exercise of its privilege. Even if this problem could be satisfyingly resolved by the Bank, it thus, results, that in the most favorable hypothesis, the average rate of return of its productive operations would be sensitively lowered ; for such a reason a revision of the contract between the bank of issue and the State should be considered.

$$
\begin{array}{r}
\text { Internal Confidential Note, Economic Studies Depart., 19 } \\
1939: 6^{\text {th }}
\end{array}
$$

By "productive operations" we should understand the traditional discounting operations of the Bank. Not only open-market was seen as an indirect form of advances in liquidity for the State, but also it would have been an unfair competition for the profit maximizing function of the Bank and its shareholders. Thus, it was not a surprise why open market had been so longly put into question.

The Bank of France's profitability debate emerged between the Rist vs Quesnay struggle as well. At the heart of the debate, the possibility for Bank of France to have different levels of interest rates prevailed. In his internal note $^{34}$ we already quoted, Rist declared as follows:

Every money that the Bank will put directly into the (money) market will set up a competition to itself. [...] The intervention on the money market interferes with the traditional monetary policy instruments which are presently at the disposal of the Bank, with regrettable effects either for the Bank itself or for the market in general.

\footnotetext{
${ }^{33}$ Bank of France archive, Reference Number: 1397199403 -66.

${ }^{34}$ Bank of France archive, Reference number: 10692008 03- 17.
} 
Rist Internal Note, 1928: 4-5

By answer, Quesnay rejected such argument by legitimating that the lower profitability return of the open-market operations would be justified only in the extent of a bad management of the asset portfolio of the Bank's balance sheet:

It is untrue to say that these operations (i.e open-market ones) will represent a competition to itself (meaning the Bank of France). If the Bank gets an asset portfolio with acceptances that will earn less than its traditional discounted commercial papers portfolio, it would be, thus, right to say that it gets a portfolio similar to that of the other banks of issue and with a totally different value from the one it traditionally hold. ${ }^{35}$

Quesnay Internal Note, 1928: 4

As we can understand, Rist and Quesnay did not speak at the same level. While Rist referred to the profitability issue of the bank, meaning Bank of France as a private commercial banks, Quesnay favored the central bank's duties and the necessity to have modern instrument so as to assure the liquidity of the banking system.

${ }^{35}$ The parenthesis are mine. 


\section{Conclusion}

The everlasting rejection of the open-market purchases was mainly driven by dogmatic reason entrusted in the person of Charles Rist and his followers. The Rist vs Quesnay debate was enlightening in this respect since it teaches us to what extent two types of policymaking get opposed in that interwar time.

As already mentioned by several leading economists (Keynes, Cassel, Schumpeter to name a few) France was static and conservative when it was question of monetary policymaking. Even after the 1938 law that officially set up open-market into the hands of Bank of France, it needed time for French policymakers to use it. However, this French monetary heterodoxy was also strategic. France did not want to loose power to the benefit of the monetary market, meaning to the benefits of the British leadership. The best way to understand the French position is to analyze it while keeping one eye on the French-British competition in the money market. Both were candidate for being at the head of the 'monetary orchestra'. Giving too much power to market would have let the doors open for the Bank of England.

Moreover, Bank of France did not want to loose its old fashioned monetary policy featured by discount rate management with a unique rate of interest. Authorizing open-market would have implied to admit that monetary policy called for changes and among them agreeing to have several types of fluctuating interest rates. Behind that static position, it is mainly the willingness of the Bank of France to keep its discretionary power that prevailed. In fact, open-market operations in its pure version would have implied to reverse the power from the Bank of France to the hands of the money market. It is for that reason that Bank of France set up in practice only a State regulated version of open-market instruments with strong legal constraints that surrounded the money market practices, i.e maximum roof for open-market purchases and fixed rates. By so doing, Bank of France maintained for a couple of years its operational autonomy against the money market control. 


\section{Appendix}

\begin{tabular}{|c|c|}
\hline Date of General Council session & Open-market Maximum Amount \\
\hline July, $7^{\text {th }}, 1938$ & $\begin{array}{l}\text { Art.8: } \\
\text { - no more than } 8 \% \text { of the gold cash reserves; } \\
\text { and } \\
\text { - no more than } 50 \% \text { of the total asset of both } \\
\text { discounted commercial papers and short term } \\
\text { (30 days) advances in liquidity }\end{array}$ \\
\hline July, $6^{t h}, 1939$ & The second item in the preceding article 8 is canceled \\
\hline February, $29^{t h}, 1940$ & $\begin{array}{l}\text { Open-market purchases amounted to } \mathbf{1 0} \text { billions of } \\
\text { French francs }\end{array}$ \\
\hline October, $29^{t h}, 1940$ & $\begin{array}{l}\text { Open-market purchases amounted to } \mathbf{1 5} \text { billions of } \\
\text { French francs }\end{array}$ \\
\hline January, $11^{\text {th }}, 1945$ & $\begin{array}{l}\text { Open-market purchases amounted to } \mathbf{4 0} \text { billions of } \\
\text { French francs }\end{array}$ \\
\hline September, $12^{t h}, 1946$ & $\begin{array}{l}\text { Open-market purchases amounted to } \mathbf{7 5} \text { billions of } \\
\text { French francs }\end{array}$ \\
\hline January, $2^{\text {nd }}, 1948$ & $\begin{array}{l}\text { Open-market purchases amounted to } \mathbf{1 2 5} \text { billions of } \\
\text { French francs }\end{array}$ \\
\hline March, $24^{t h}, 1949$ & $\begin{array}{l}\text { Open-market purchases amounted to } \mathbf{1 5 0} \text { billions of } \\
\text { French francs }\end{array}$ \\
\hline May, $19^{t h}, 1949$ & $\begin{array}{l}\text { Open-market purchases amounted to } 200 \text { billions of } \\
\text { French francs }\end{array}$ \\
\hline May, $4^{t h}$ and $10^{t h}, 1951$ & $\begin{array}{l}\text { The maximum amount of } 200 \text { billion can be ex- } \\
\text { ceeded. }\end{array}$ \\
\hline May, $21^{s t}, 1951$ & $\begin{array}{l}\text { Open-market purchases amounted to } \mathbf{2 5 0} \text { billions of } \\
\text { French francs }\end{array}$ \\
\hline June, $28^{t h}, 1951$ & $\begin{array}{l}\text { The maximum amount of } 250 \text { billions can be ex- } \\
\text { ceeded. }\end{array}$ \\
\hline August, $2^{\text {nd }}, 1951$ & $\begin{array}{l}\text { The maximum amount of } 250 \text { billions can be ex- } \\
\text { ceeded. The decision to increase the maximum } \\
\text { amount is delayed to a further session. }\end{array}$ \\
\hline October, $18^{t h}, 1951$ & $\begin{array}{l}\text { It is seen as preferable to wait before deciding to } \\
\text { an upper level of maximum amount of open-market } \\
\text { purchases. }\end{array}$ \\
\hline May, $19^{t h}, 1949$ & $\begin{array}{l}\text { Open-market purchases amounted to } 200 \text { billions of } \\
\text { French francs }\end{array}$ \\
\hline December, $20^{t h}, 1951$ & $\begin{array}{l}\text { The maximum amount of } 250 \text { billions can be ex- } \\
\text { ceeded. }\end{array}$ \\
\hline March, $27^{t h}, 1952$ & $\begin{array}{l}\text { The maximum amount of } 250 \text { billions can be ex- } \\
\text { ceeded once more. }\end{array}$ \\
\hline April, $3^{\text {rd }}, 1952$ & $\begin{array}{l}\text { Open-market purchases amounted to } \mathbf{3 0 0} \text { billions of } \\
\text { French francs }\end{array}$ \\
\hline June, $28^{t h}, 1956$ & $\begin{array}{l}\text { The maximum amount of } 300 \text { billions can be ex- } \\
\text { ceeded. }\end{array}$ \\
\hline November, $28^{t h}, 1968$ & $\begin{array}{l}\text { The maximum amount of open-market purchases is } \\
\text { cancel30. }\end{array}$ \\
\hline
\end{tabular}

Table 1: Open-Market Maximum Amount granted by the General Council of the Bank of France

Source: Bank of France archive, Reference Number: 10692008 03- 17. 


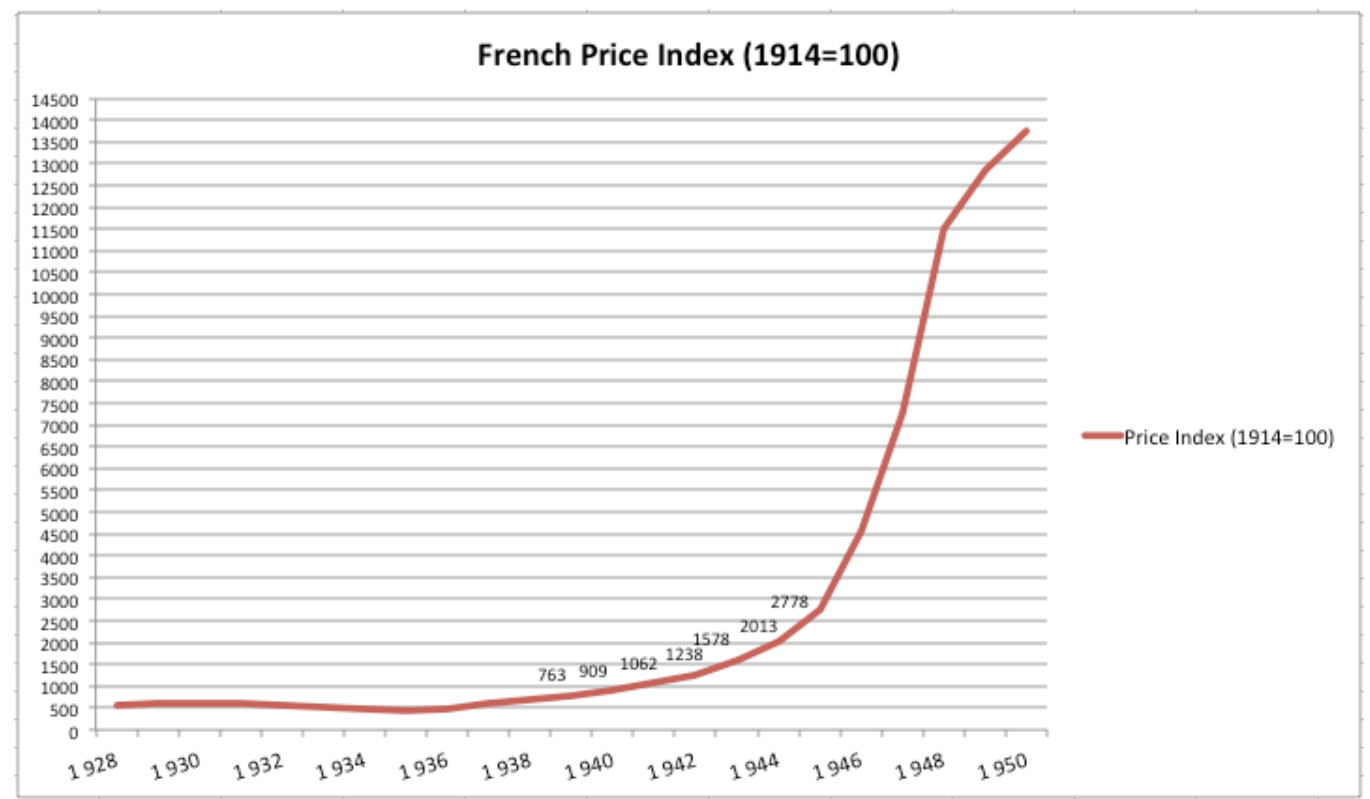

Figure 1: French Price Index (1914-1950)

Source: A. Maddisson, 1981, Annexe E-7, p.300. 


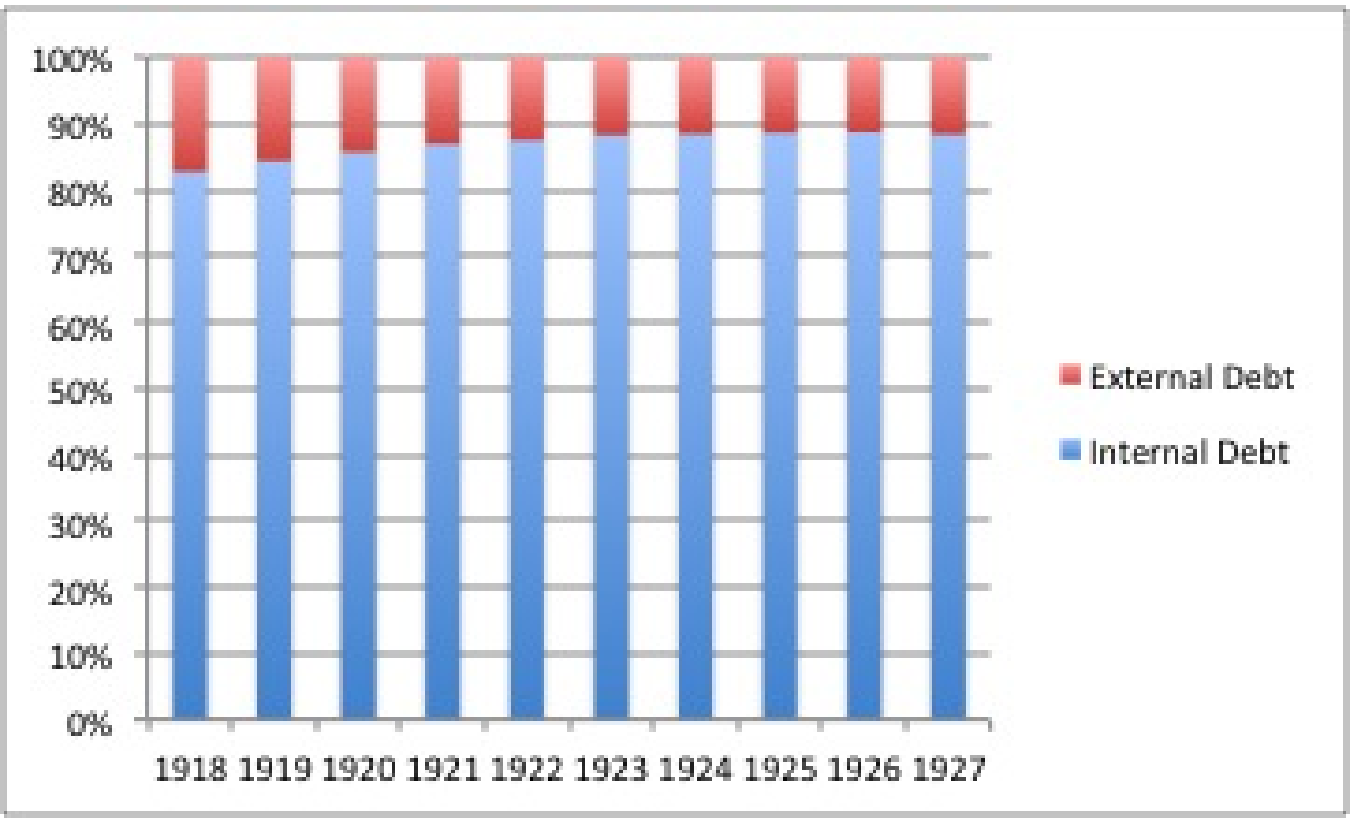

Figure 2: French Debt Structure (1918-1927)

Source: Dulles (1929: 244) 


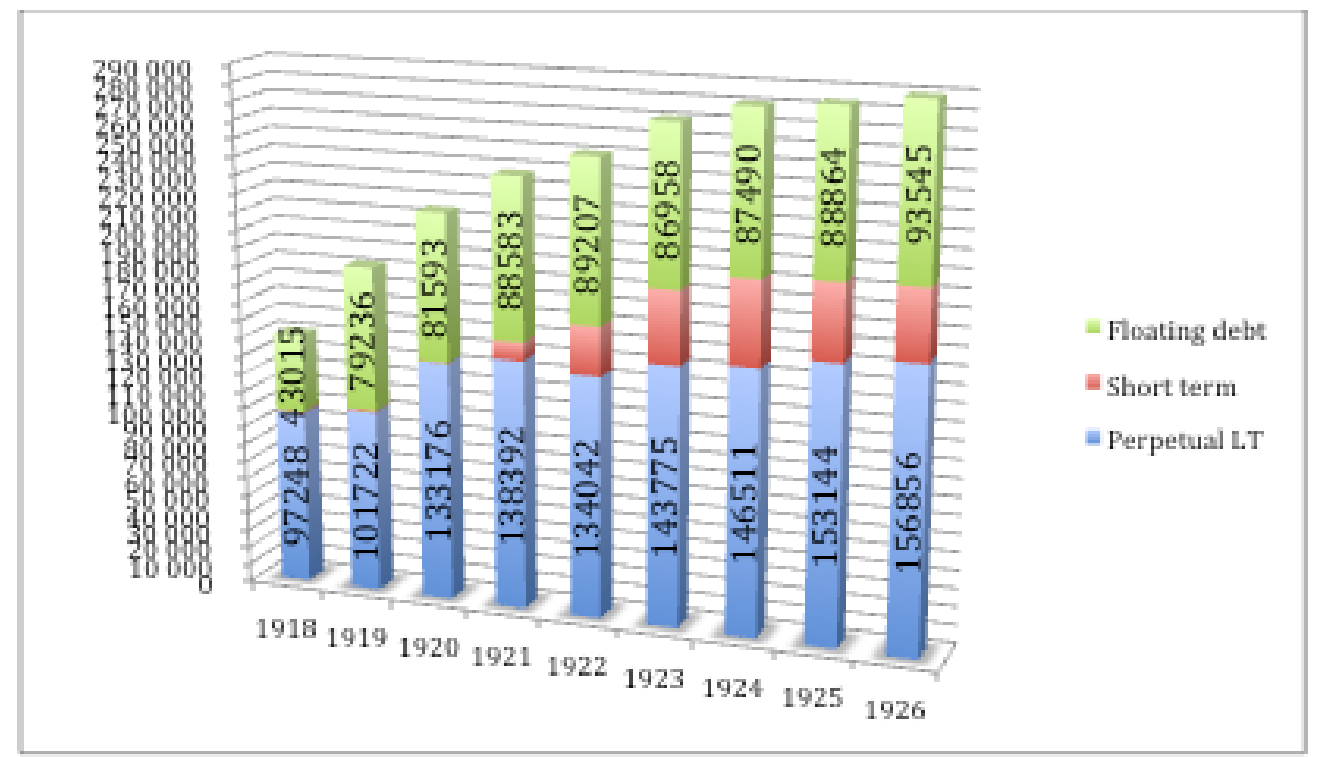

Figure 3: French Internal Debt Structure (1918-1927)

Source: Dulles (1929: 244) 


\section{References}

Barbaroux, N. (2013). Monetary Policy Rule in Theory and Practice: facing internal versus external stability dilemma. International Studies in Money and Banking Series. London and New York: Routledge.

Bellet, M., S. Gloria-Palermo, and A. Zouache (Eds.) (2004). Evolution of the Market Process. Austrian and Swedish Economics,. London and New York: Routledge.

Blancheton, B. (2001). Le Pape et l 'Empereur. Albin Michel.

Dehem, R. (1988). New Palgrave Dictionnary of Economics, Volume 4, Chapter "Charles Rist", pp. 206. Mac Millan.

Dulles, E. L. (1929). The French Franc. Mac Millan Company.

Fontana, G. (2000). Les Traditions Economiques Françaises (1848-1939), Chapter 'Bank, Credit and the Creation od Deposits: The original contribution of Emile Mireaux, pp. 235-246. CNRS Edition.

Giannone, D., M. Lenza, H. Pill, and L. Reichlin (2012). The ecb and the interbank market. ECARES Working Paper 2012-005.

Goodhart, C.-A.-E. (1988). The Evolution of Central Banks. MIT Press.

Kydland, F.-E. and E. Prescott (1977). Rules rather than discretion: The inconsistency of optimal plans. In T. Persson and G.Tabellini (Eds.), Monetary and Fiscal Policy, Volume 85, pp. 35-55. MIT Press.

Maddisson, A. (1981). Les Phases du Développement Capitaliste. Paris: Economica.

Moreau, E. (1954). Souvenirs d'un Gouverneur de la Banque de France. Histoire de la stabilisation du Franc (1926-1928). Paris: Genin.

Mouré, K. (1998). La politique du franc Poincarré (1926-1936).

Quesnay, P. (1932). L'internationalisme monétaire et ses conditions d'application. Revue de Science et de législation financière, 30, 79-107.

Rist, C. (1927). La Déflation en pratique (2nd ed.). Giard Edition.

Rist, C. (2002 [1938]). Histoire des Doctrines relatives au crédit et à la monnaie de John Law jusqu'à nos jours. Dalloz.

Schumpeter, J. A. (1954). History of Economic Analysis. Oxford University Press.

Simons, H. C. (1936). Rules versus Authorities in Monetary Policy. Journal of Political Economy 44, 1-30. 
Taylor, J. B. and J. C. Williams (2009). A Black Swan in the Money Market. American Economic Journal: Macroeconomics 1(1), 58-83.

Trautwein, H.-M. and M. Boianovsky (2001). An early manuscript by knut wicksell on the bank rate of interest. History of Political Economy 33(3), 485-507.

Wicksell, K. (1936 [1898]). Interest and Prices A Study of the Causes Regulating the Value of Money. Macmillan and Co. 